\title{
A case of morning headache:Doege-Potter syndrome
}

\section{Saifuddin Kassim, Isabelle Vanheeswijk, Anita Pillai, Emma Robinson, Jhittay Harsimar, Ruth Maclnerney}

\section{Diabetes and Endocrinology, Chesterfield Royal Hospital, UK}

\section{Introduction}

Tumour induced hypoglycaemia is a rare disorder occurring in cancer patients caused by variety of tumours including islet and non-islet tumours. Non-islet cell tumour induced hypoglycaemia (NICTH) is rare paraneoplastic disorders normally associated with pleural solitary fibrous tumour but can also rarely occur in extra thoracic site.

\section{Case Report}

We describe 86 year old man not known to have diabetes mellitus who presented with 3 month history of early morning headache and dizziness relieved by consuming large amount of fizzy sweet drinks. On examination, he was noted to have large palpable mass on the left upper quadrant

\section{Investigation}

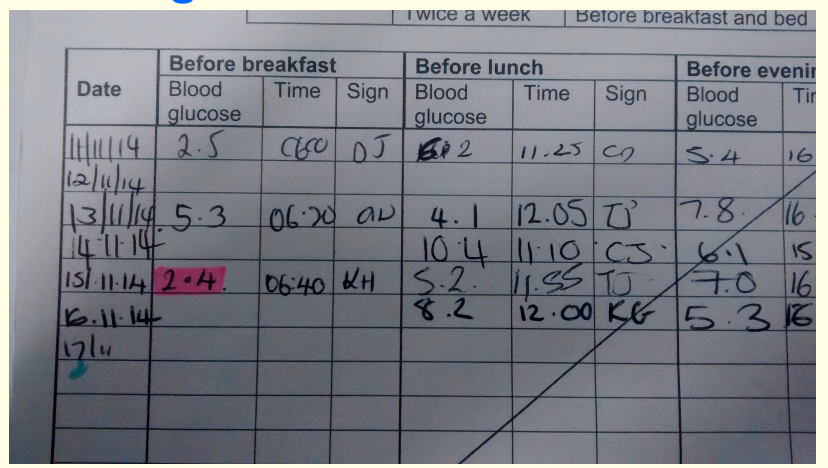

Fig 1 Capillary glucose monitoring showing pattern of early morning hypoglycaemia

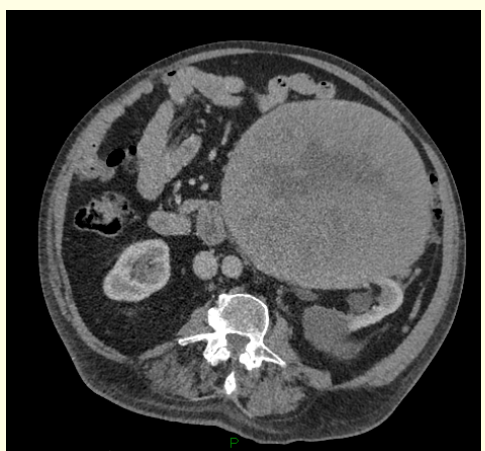

Fig 2 CT scan of the abdomen revealed huge solitary $22 \mathrm{~cm} \times$ $19 \mathrm{~cm} \times 16 \mathrm{~cm}$ well defined, rounded solid heterogeneous retroperitoneal mass with internal ill-defined areas of necrosis

\begin{tabular}{|c|c|c|}
\hline & Result & Normal Range \\
\hline Plasma Glucose & 2.4 & $3.9-5.5 \mathrm{mmol} / /$ \\
\hline Insulin & $<1.0$ & $17.8-173 \mathrm{pmol} / \mathrm{l}$ \\
\hline C Peptide & 81 & $298-2350 \mathrm{pmol} / \mathrm{I}$ \\
\hline 3-hydroxybutyrate & $<0.1$ & $0.3-0.5 \mathrm{mmol} / /$ \\
\hline Free fatty acid & 0.3 & $0.00-0.72 \mathrm{mmol} / \mathrm{I}$ \\
\hline IGF-1 & 7.1 & $6-36 \mathrm{nmol} / \mathrm{I}$ \\
\hline IGF-2 & 94.5 & $\mathrm{nmol} / /$ \\
\hline IGF-2/IGF-1 ratio & 13.3 & Ratio $<10$ \\
\hline Short Synachten Test (0 & $298 / 874$ & Normal response peak of \\
minute/ 30 minute) & & $>500 \mathrm{nmol} / \mathrm{I}$ \\
\hline Serum Sulphonlyureas & Undetectable & $11-26 \mathrm{pmol} / \mathrm{l}$ \\
\hline FT4 & 15.5 & $0.4-5.5 \mathrm{mU} / /$ \\
\hline TSH & 6.7 & \\
\hline
\end{tabular}

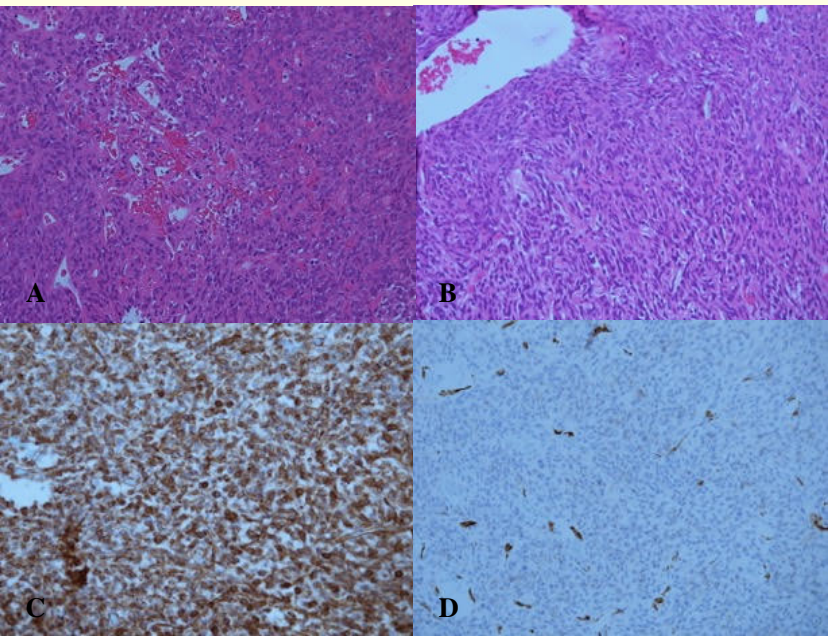

Fig 3 Core biopsy of renal mass : Haematoxylin eosin staining showing cellular spindle cell proliferation with "patternless" architecture and stag horn-like vessels (Image A, B)

Immunohistology showing positive CD-34 expression (Image C) and negative SMA (smooth muscle actin) (Image D)

Courtesy of Dr Sheikh Saleh (Consultant Histopathologist, Chesterfield Royal Hospital)

\section{Discussion}

Investigation results were consistent with diagnosis of $\mathrm{NICTH}$ secondary to extra thoracic solitary fibrous tumour. Solitary fibrous tumour are mesenchymal tumour thought to be of fibroblastic origin. It can be rarely associated with hypertrophic pulmonary osteoarthropathy (Pierre Marie-Bamberger syndrome) or/and refractory hypoglycaemia (Doege-Potter syndrome) ${ }^{1}$.

Effective and ideal treatment would be surgical resection but in this case this was not feasible given patients comorbidity. Symptomatic treatment has been achieved using various modalities including administration of glucagon, somatostatin analogue, growth hormone and glucocorticoid ${ }^{2}$. He was managed conservatively with oral dexamethasone $1.5 \mathrm{mg}$ od which resolves the recurrent hypoglycaemic episodes.

Overall mortality for 5 year and 10 year disease specific survival rates are $89 \%$ and $73 \%$ respectively.

\section{Conclusions}

In summary, we have described a rare phenomenon of DoegePotter syndrome, a paraneoplastic phenomenon of hypoglycaemia associated with rare extra thoracic solitary fibrous tumour. It is important to investigate the aetiology thoroughly as management can be tailored individually for each patient.

\section{Reference}

1 Kalebi AY et al. Surgically cured hypoglycemia secondary to pleural solitary fibrous tumour: case report and update review on the Doege-Potter syndrome. $J$ Cardiothorac Surg. 2009;4:45

2 Teale JD, Wark G. The effectiveness of different treatment options for non-islet cell tumour hypoglycaemia. Clin Endocrinol (Oxf). 2004;60(4):457-460 